\title{
Dermatofibrosarcoma protuberans of the vulva: margins assessment and reconstructive options - a report of two cases
}

Eduardo Bertolli $i^{*}$, Eduard Renè Bretchbuhl ${ }^{1}$, William Ricardo Camarço ${ }^{1}$, Mariane Campagnari ${ }^{1}$, André Sapata Molina ${ }^{1}$, Glauco Baiocchi ${ }^{2}$, Mariana Petaccia de Macedo ${ }^{3}$, Clovis Antonio Lopes Pinto ${ }^{3}$, Isabela Werneck da Cunha ${ }^{3}$ and João Pedreira Duprat Neto'

\begin{abstract}
Background: Dermatofibrosarcoma Protuberans (DFSP) of the vulva is rare and oncologic surgery with free margins may lead to severe functional damage, requiring multidisciplinary approach regarding resection, margin assessment and reconstruction.

Case Report: Two cases of DFSP in vulva were treated in a single institution. A 28-year-old patient with an incisional biopsy in the vulvar region revealing DFSP underwent a partial vulvectomy with clitoris preservation. Pathological studies revealed free margins and reconstructive surgery was performed. This patient is disease free in a 40 months follow up. The other, a 57-year-old patient was also referred after an incomplete resection of a DFSP in the vulvar region. A 1-cm margim resection followed by Complete Circumferential and Peripheral Deep Margin Assessment (CCPDMA) was performed. Although the upper lateral margin was positive, it was possible to perform another wide local excision with preservation of the clitoris and primary closure.

Conclusion: DFSP of the vulva requires an accurate evaluation of margins, resections following oncological principles and reconstruction. Although being a very challenging lesion that usually implies difficult surgical management, if treated in a multidisciplinary environment, with surgical oncologists, experienced dermatopathologists and reconstructive surgeons can achieve good results. Even in difficult cases that presents with large lesions and compromising challenging areas, a complete oncologic resection can be performed minimizing functional damage for the patient.
\end{abstract}

Keywords: DFSP, Vulva, CCPDMA, Reconstruction, Surgical oncology

\section{Background}

Dermatofibrosarcoma protuberans (DFSP) is a rare skin mesenchymal tumor that usually affects the trunk and extremities. Vulvar DFSP is rare, with fewer than 40 cases previously reported in the literature [1,2]. Surgery has been reported as the main therapeutic option for DFSP treatment. However, there is no consensus on margin assessment protocols. The most frequently used techniques are Mohs surgery, wide local excision (WLE) with 2.0 or $3.0 \mathrm{~cm}$ margins and surgery followed by

\footnotetext{
* Correspondence: ebertolli@hotmail.com

'Skin Cancer Department, AC Camargo Cancer Center, Rua Professor Antonio Prudente 211, 01509-900 São Paulo, Brazil

Full list of author information is available at the end of the article
}

three-dimensional complete circumferential and peripheral deep margin assessment (CCPDMA) [3-6].

The CCPDMA technique consists of excising the tumor with a margin smaller than the traditional $3.0-\mathrm{cm}$ one. The specimen is submitted to conventional histologic processing and margins are completely evaluated by the pathologist. Additional study with immunohistochemistry (IHC) may be useful for margin assessment in some doubtful cases. This technique is associated with a more accurate evaluation of the margins and literature reports rates of recurrence lower than $10 \%[5,7]$.

Another very important aspect of surgery in vulvar DFSP is the clitoris preservation and reconstruction after the lesion is removed, because this directly affects 


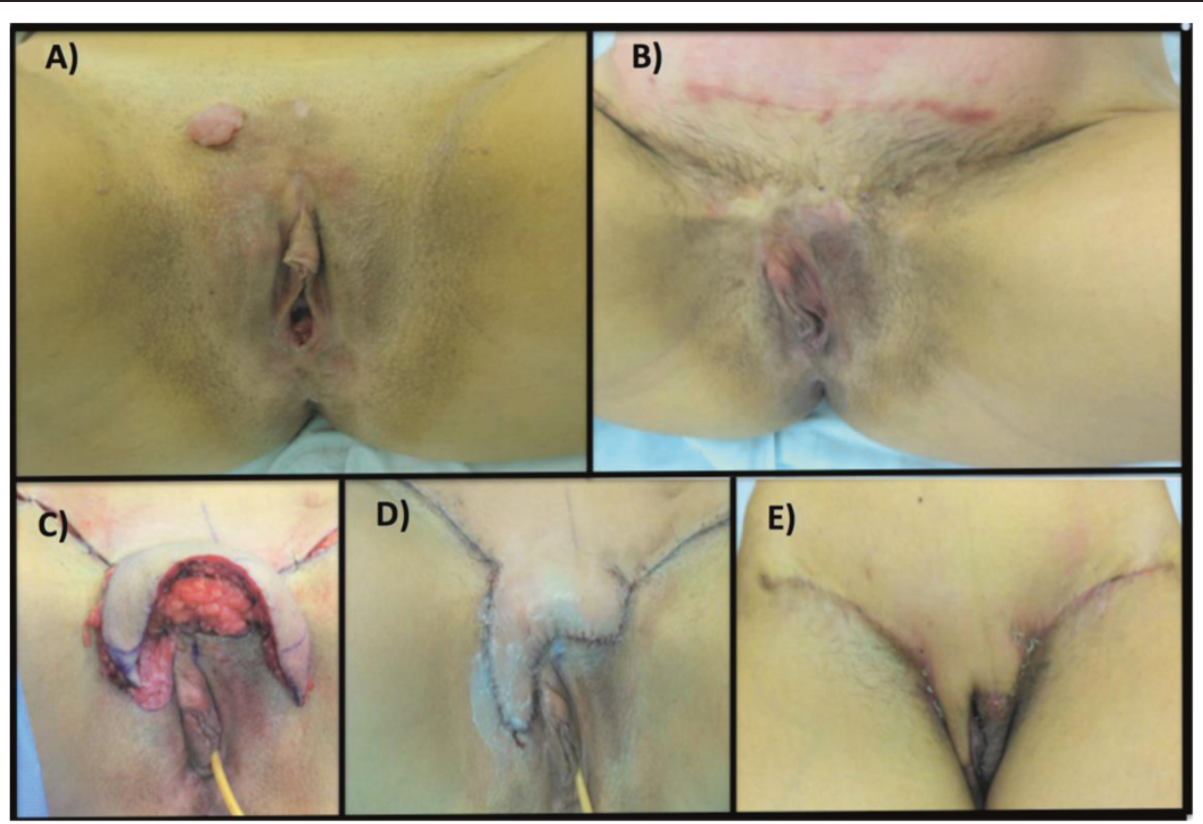

Figure 1 Patient 1. (A) Clinical aspect of the residual lesion of dermatofibrosarcoma protuberans of the vulva before the surgery. (B) One year after the first surgery, a skin expander was placed. (C) The expander was taken out and the inferior 2/3 of the flap was split. (D) the distal portion was incised horizontally on both sides and folded after, in order to reconstruct the labius majoras. (E) Follow up after 8 weeks.

sexuality and quality of life of these patients $[8,9]$. Better results are achieved with a multidisciplinary approach. The objective of this study was to present two cases of vulvar DFSP managed by the Skin Cancer and Gynecology Oncology Departments of AC Camargo Cancer Center with minimal functional damage for the patient. This case report was approved for publication by Fundação Antonio Prudente ethics committee.

\section{Case presentation}

The first case is a 28 -year-old female patient referred to us after an incisional biopsy in the vulvar region revealing DFSP. She presented to us with a $5.0-\mathrm{cm}$ lesion in the mons pubis (Figure 1A). Surgery was indicated, and consisted of a vulvectomy with a local advancement flap as the first approach in order to obtain a $2.0 \mathrm{~cm}$ margin from the tumor. Margins were assessed by CCPDMA protocols and they were all free of disease. Therefore, it was possible to avoid clitoris resection.

To perform the vulvar reconstruction, a skin expander was placed in the inferior part of the abdominal wall one year after vulvectomy (Figure 1B). Weekly expansion was performed 3 weeks after the procedure and, in the third month, sufficient skin was attained in this area. The expander was taken out and the inferior $2 / 3$ of the flap was split. The skin of the mons pubis was decorticated and the medium and proximal portions of the flap were advanced to protect the pubis bone. The distal portion was incised horizontally on both sides and folded after, in order to reconstruct the labius majoras (Figure $1 \mathrm{C}$ and $\mathrm{D}$ ).
This patient has been followed for almost 40 months (Figure 1E). There is no clinical or radiological evidence of recurrence. Regarding the surgery, we considered that a very adequate aesthetic effect was achieved. The patient verbally reported good quality of life, although no quality of life (QOL) questionnaires were applied.

The second case is a 57-year-old female patient, also referred to our hospital after an incomplete resection of a DFSP in the vulvar region. She presented to us with a $2.0 \mathrm{~cm}$ residual lesion in the right labium major. As the lesion was too close to the clitoris, we performed a $1.0-\mathrm{cm}$ margin

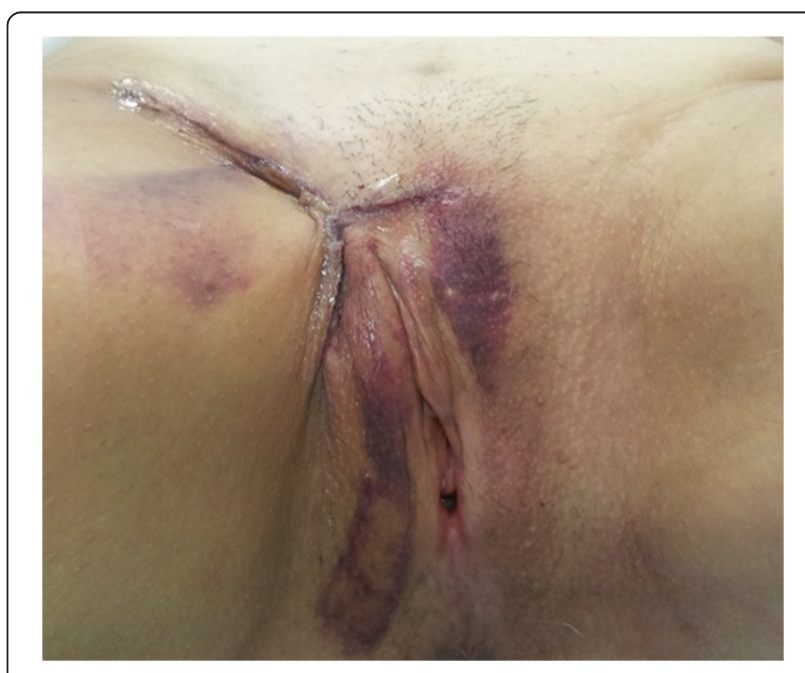

Figure 2 Patient 2: final clinical aspect of the second surgery when primary closure was performed twice. 
Table 1 Summary of the reported cases of Dermatofibrosarcoma Protuberans of the vulva with clinical, treatment and follow up information

\begin{tabular}{|c|c|c|c|c|c|c|}
\hline Author & Cases & Age, years & Clinical presentation & Size, cm & Initial treatment & Outcome/follow up \\
\hline $\begin{array}{l}\text { Edelweiss and } \\
\text { Malpica [1] }\end{array}$ & 1 & 36 & $\begin{array}{l}\text { Right labium major } \\
\text { mass }\end{array}$ & 5 & Excisional biopsy & LR at 12 months. AWD at 16 months \\
\hline $\begin{array}{l}\text { Edelweiss and } \\
\text { Malpica [1] }\end{array}$ & 2 & 57 & $\begin{array}{l}\text { Right labium major } \\
\text { mass }\end{array}$ & 3 & Excisional biopsy & $\begin{array}{l}\mathrm{LR} \text { at } 60 \text { months, then WLE ( } 2 \mathrm{x} \text { ) until } \\
\text { negative margin. NED at } 216 \text { months. }\end{array}$ \\
\hline $\begin{array}{l}\text { Edelweiss and } \\
\text { Malpica [1] }\end{array}$ & 3 & 69 & Mons pubis mass & 3 & Excisional biopsy + WLE & Dead of other causes at 144 months \\
\hline $\begin{array}{l}\text { Edelweiss and } \\
\text { Malpica [1] }\end{array}$ & 4 & 48 & Left paraclitoral mass & 1.2 & Excisional biopsy + WLE & LR, then WLE. NED at 144 months. \\
\hline $\begin{array}{l}\text { Edelweiss and } \\
\text { Malpica [1] }\end{array}$ & 5 & 46 & $\begin{array}{l}\text { Right labium major } \\
\text { pigmented lesion }\end{array}$ & 4 & $\begin{array}{l}\text { Excisional biopsy }+ \\
\text { WLE }(\times 2)\end{array}$ & NED at 84 months. \\
\hline $\begin{array}{l}\text { Edelweiss and } \\
\text { Malpica [1] }\end{array}$ & 6 & 76 & $\begin{array}{l}\text { Right labium major } \\
\text { and crural fold mass }\end{array}$ & 15 & Excisional biopsy + WLE & $\begin{array}{l}\text { LR at } 7 \text { months, then WLE with negative } \\
\text { margin. At } 14 \text { months, metastasis to chest } \\
\text { wall. At } 18 \text { months, metastasis to hip and } \\
\text { thigh. Death of the disease at } 34 \text { months. }\end{array}$ \\
\hline $\begin{array}{l}\text { Edelweiss and } \\
\text { Malpica [1] }\end{array}$ & 7 & 44 & $\begin{array}{l}\text { Left labium major } \\
\text { mass }\end{array}$ & 4 & Excisional biopsy + WLE & NED at 53 months \\
\hline $\begin{array}{l}\text { Edelweiss and } \\
\text { Malpica [1] }\end{array}$ & 8 & 39 & $\begin{array}{l}\text { Right labium major } \\
\text { mass }\end{array}$ & N/A & WLE & $\begin{array}{l}\text { LR at } 48 \text { months. Then, WLE with positive } \\
\text { margin. At } 60 \text { months, local recurrence. } \\
\text { Then WLE with positive margin. Used Gleevec. } \\
\text { NED at } 72 \text { months }\end{array}$ \\
\hline $\begin{array}{l}\text { Edelweiss and } \\
\text { Malpica [1] }\end{array}$ & 9 & 30 & $\begin{array}{l}\text { Right labium major } \\
\text { and mons pubis mass }\end{array}$ & N/A & $\begin{array}{l}\text { Excisional biopsy }+ \\
\text { WLE }\end{array}$ & $\begin{array}{l}\text { LR at } 11 \text { months. Then, WLE. AWD at } \\
24 \text { months }\end{array}$ \\
\hline $\begin{array}{l}\text { Edelweiss and } \\
\text { Malpica [1] }\end{array}$ & 10 & 23 & $\begin{array}{l}\text { Right labium major } \\
\text { mass }\end{array}$ & 4 & $\begin{array}{l}\text { Excisional biopsy }+ \\
\text { WLE }\end{array}$ & NED at 2 months \\
\hline $\begin{array}{l}\text { Edelweiss and } \\
\text { Malpica [1] }\end{array}$ & 11 & 30 & $\begin{array}{l}\text { Left labium major } \\
\text { mass }\end{array}$ & N/A & Excisional biopsy & $\begin{array}{l}\text { LR at } 60 \text { months followed by WLE with } \\
\text { positive margin. Then, partial vulvectomy } \\
\text { with negative margin. NED at } 96 \text { months }\end{array}$ \\
\hline $\begin{array}{l}\text { Edelweiss and } \\
\text { Malpica [1] }\end{array}$ & 12 & 44 & $\begin{array}{l}\text { Right labium major } \\
\text { mass }\end{array}$ & 2.5 & $\begin{array}{l}\text { Excisional biopsy }+ \\
\text { radical vulvectomy }\end{array}$ & NED at 36 months \\
\hline $\begin{array}{l}\text { Edelweiss and } \\
\text { Malpica [1] }\end{array}$ & 13 & 58 & $\begin{array}{l}\text { Paraclitoral mass } \\
\text { extending into vagina }\end{array}$ & 4.8 & WLE & NED at 3 months \\
\hline Soltan [10] & 14 & 83 & $\begin{array}{l}\text { Left labium major/ } \\
\text { minor nodule }\end{array}$ & 5 & Excisional biopsy & N/A \\
\hline $\begin{array}{l}\text { Agress et al. } \\
{[11]}\end{array}$ & 15 & 56 & Left labium major & N/A & Excisional biopsy & $L R$, then WLE \\
\hline Bock et al. [12] & 16 & 52 & Right mons pruritus & 8 & Excisional biopsy & $L R$, then WLE \\
\hline $\begin{array}{l}\text { Barnhill et al. } \\
{[13]}\end{array}$ & 17 & 42 & $\begin{array}{l}\text { Right vulva lateral to } \\
\text { clitoris nodule }\end{array}$ & 1 & Excisional biopsy & LR, then WLE and hemivulvectomy \\
\hline Leake et al. [14] & 18 & 37 & $\begin{array}{l}\text { Left mons and labium } \\
\text { major nodule }\end{array}$ & 6.2 & Excisional biopsy & $L R$, then wide radical excision \\
\hline Leake et al. [14] & 19 & 59 & $\begin{array}{l}\text { Right labium major } \\
\text { nodule }\end{array}$ & 5 & Excisional biopsy & $L R$, then partial radical vulvectomy \\
\hline $\begin{array}{l}\text { Panidis et al. } \\
{[15]}\end{array}$ & 20 & 30 & $\begin{array}{l}\text { Right labium major } \\
\text { nodule }\end{array}$ & 2 & WLE & $L R$, then radical vulvectomy \\
\hline $\begin{array}{l}\text { Aartsen and } \\
\text { Albus-Lutter } \\
{[16]}\end{array}$ & 21 & 50 & N/A & 1.2 & Radical vulvectomy & N/A \\
\hline $\begin{array}{l}\text { Karlen et al. } \\
{[17]}\end{array}$ & 22 & 36 & $\begin{array}{l}\text { Left labium major } \\
\text { irritated lump }\end{array}$ & 5 & WLE & N/A \\
\hline $\begin{array}{l}\text { Nirenberg et al. } \\
{[18]}\end{array}$ & 23 & 41 & $\begin{array}{l}\text { Left labium major } \\
\text { lump }\end{array}$ & 8 & WLE & N/A \\
\hline \multirow[t]{2}{*}{$\begin{array}{l}\text { Alverez-Canas } \\
\text { [19] }\end{array}$} & 24 & 58 & $\begin{array}{l}\text { Left labium major } \\
\text { mass }\end{array}$ & 3.2 & WLE & $\mathrm{N} / \mathrm{A}$ \\
\hline & 25 & 47 & & 3 & & - radiotherapy \\
\hline
\end{tabular}


Table 1 Summary of the reported cases of Dermatofibrosarcoma Protuberans of the vulva with clinical, treatment and follow up information (Continued)

\begin{tabular}{|c|c|c|c|c|c|c|}
\hline \multicolumn{3}{|l|}{$\begin{array}{l}\text { Soergel et al. } \\
\text { [20] }\end{array}$} & \multicolumn{2}{|l|}{$\begin{array}{l}\text { Left vulva mass + lung } \\
\text { metastasis }\end{array}$} & \multicolumn{2}{|l|}{$\begin{array}{l}\text { Partial radical } \\
\text { vulvectomy + } \\
\text { chemotherapy }\end{array}$} \\
\hline $\begin{array}{l}\text { Ghorbani et al. } \\
{[21]}\end{array}$ & 26 & 47 & Left paraclitoral area & N/A & Hemivulvectomy & $L R$, then wide radical excision \\
\hline $\begin{array}{l}\text { Ghorbani et al. } \\
{[21]}\end{array}$ & 27 & 44 & Left labium major mass & 4 & Wide radical excision & N/A \\
\hline $\begin{array}{l}\text { Ghorbani et al. } \\
\text { [21] }\end{array}$ & 28 & 66 & Mons mass & 1.5 & WLE & N/A \\
\hline $\begin{array}{l}\text { Ghorbani et al. } \\
\text { [21] }\end{array}$ & 29 & 36 & Right labium mass & 5 & Excsional biopsy & N/A \\
\hline $\begin{array}{l}\text { Moodley and } \\
\text { Moodley [22] }\end{array}$ & 30 & 39 & Left labium major mass & 12 & WLE & N/A \\
\hline Vanni et al. [23] & 31 & 39 & $\begin{array}{l}\text { Inferior vulva/ } \\
\text { perineum mass }\end{array}$ & 6 & WLE & N/A \\
\hline $\begin{array}{l}\text { Kholova et al. } \\
{[24]}\end{array}$ & 32 & 31 & $\begin{array}{l}\text { Left labium major } \\
\text { recurrent nodule }\end{array}$ & 1.5 & Excisional biopsy & $L R$, then WLE + radiotherapy \\
\hline $\begin{array}{l}\text { Ohlinger et al. } \\
\text { [25] }\end{array}$ & 33 & 36 & Left vulva nodule & 2.8 & Excisional biopsy & $L R$, then WLE \\
\hline $\begin{array}{l}\text { Hancox et al. } \\
{[26]}\end{array}$ & 34 & 55 & $\begin{array}{l}\text { Right labium major } \\
\text { mass }\end{array}$ & 8 & MMS & NED \\
\hline $\begin{array}{l}\text { Hammonds } \\
\text { and Hendi [6] }\end{array}$ & 35 & 59 & $\begin{array}{l}\text { Right labium major } \\
\text { mass }\end{array}$ & 4 & MMS & NED \\
\hline $\begin{array}{l}\text { Doufekas et al. } \\
\text { [3] }\end{array}$ & 36 & 39 & $\begin{array}{l}\text { Left labium major } \\
\text { nodule }\end{array}$ & N/A & Incisional biopsy & $\begin{array}{l}\text { MMS with primary closure. } \\
\text { NED at } 3 \text { years }\end{array}$ \\
\hline $\begin{array}{l}\text { Zizi- } \\
\text { Sermpetzoglou } \\
\text { et al. [27] }\end{array}$ & 37 & 66 & Mons pubis & N/A & WLE & NED \\
\hline
\end{tabular}

N/A, not available; WLE, wide local excision; MMS, Mohs micrographic surgery; LR, local recurrence; AWD, alive with disease; AWOD, alive without disease; NED, no evidence of disease).

instead of the traditional $2.0-\mathrm{cm}$ one, followed by primary closure. The CCPDMA revealed all positive margins except for the upper lateral region of the specimen. The patient was submitted to another WLE of $2.0 \mathrm{~cm}$ and subsequent primary closure could be performed once more (Figure 2A). This patient has been followed for 10 months without any aesthetic or functional issue related to the surgery.

\section{Conclusion}

Regardless being a very rare disease, DFSP in the vulva represents a very challenging situation for the oncologic and plastic surgeons. The resection must follow oncological principles, which sometimes may lead to several aesthetic and functional impacts for the patient due to the difficulty in planning how wide the resection should be [4]. In this context, reconstructive surgery plays a fundamental role in the management of DFSP patients.

There are just few cases of vulvar DFSP reported in the literature. See Table 1 for a summary of previously reported cases of DFSP in the vulva with clinical, treatment and follow-up information. The largest series, from the MD Anderson Cancer Center, reported 13 cases. All of the six cases with positive margins after resection developed tumor recurrence. There was only one relapse between the cases with negative margins after WLE that occurred in a patient showing fibrosarcomatous transformation in the recurrent tumor [1].

Based on this paper, the role of an adequate assessment of margins in these cases can be assumed. In our service, the protocol is to submit the specimen to conventional histologic processing with complete evaluation of the margins by CCPDMA by the pathologist, and IHC study whenever necessary $[2,5]$. The morphologic and molecular pathologic findings of vulvar DFSP are quite similar to DFSP in other sites, including the frequent finding of the fusion between collagen type I alpha 1 gene (COL1A1) on chromosome 17 and the platelet-derived growth factor B-chain (PDGFB) gene on chromosome 22 [23,28].

There is also scarce literature on reconstructive options in vulvar DFSP. There are two recent reports on Mohs surgery for vulvar DFSP, and both were submitted to primary closure $[3,6]$. No data related to clitoris preservation or major vulvar reconstructions have been found.

Skin expansions are often used to reconstruct burned areas or breasts after a mastectomy or to hide scars [29]. Although there is no strong evidence in the literature to 
supports its use in skin tumors, we believe that it can be safely used since the tumor resection is not delayed because of the use of the expansion. Also, in our case we have had a very rigorous assessment of the pathological margins to ensure that the resection was complete. Moreover, the patient was kept for over a year in clinical follow up before starting the expansion.

Our first case illustrates an example of a major vulvar reconstruction using skin expansion followed by a skin and fat tissue flap. Although it has been done in only one patient, the clinical outcome suggests this can be a feasible option in such cases. Both our patients were submitted to clitoris-sparing surgery, which was only possible due to the utilization of the CCPDMA protocol by our Pathology Department.

We conclude that vulvar DFSP, although a very challenging lesion that usually implies difficult surgical management, if treated in a multidisciplinary environment with surgical oncologists, experienced pathologists and reconstructive surgeons, can achieve good results. And even in difficult cases that present with large lesions and compromising challenging areas, a complete oncologicresection can be performed, minimizing functional damage for the patient.

\section{Abbreviations}

DFSP: dermatofibrosarcoma protuberans; WLE: wide local excision; CCPDMA: 3-dimensional complete circumferential and peripheral deep margin assessment; IHC: immunohistochemistry; COL1A1: collagen type I alpha 1; PGDF: Platelet-derived growth factor B-chain.

\section{Competing interests}

The authors declare that they have no competing interests.

\section{Authors' contributions}

The Skin Cancer Department staff (EB, ERB, WRC, MC, ASM, JPDN) was involved in the diagnosis, management and post-operative recovery of the patients. The Gynecology Oncology Department staff (GB) was also involved with the operative proceedings in both cases. The Pathology department (MPM, IWC, CALP) was responsible for the CCPDMA and pathological reports in both cases. All authors have contributed with the literature review and with the preparation of this manuscript. All authors read and approved the final manuscript.

\section{Acknowledgement}

We acknowledge A.C. Camargo Cancer Center for institutional support.

\section{Author details}

${ }^{1}$ Skin Cancer Department, AC Camargo Cancer Center, Rua Professor Antonio Prudente 211, 01509-900 São Paulo, Brazil. ${ }^{2}$ Gynecologic Oncology Department, AC Camargo Cancer Center, Rua Professor Antonio Prudente 211, 01509-900 São Paulo, Brazil. ${ }^{3}$ Pathology Department, AC Camargo Cancer Center, Rua Professor Antonio Prudente 211, 01509-900 São Paulo, Brazil.

Received: 18 August 2014 Accepted: 3 December 2014

Published: 29 December 2014

\section{References}

1. Edelweiss M, Malpica A: Dermatofibrosarcoma protuberans of the vulva: a clinicopathologic and immunohistochemical study of 13 cases. Am J Surg Pathol 2010, 34:393-400.

2. Molina AS: Dermatofibrossarcoma protuberans: Análise dos marcadores de proliferação celular, invasividade e apoptose. Estudo da fusão de col-1a1/pdgf- $\beta$ por fish e correlação com a recidiva. MSc thesis. Fundação Antonio Prudente, Oncology; 2011 [http://accamargo.phlnet.com. br/MESTRADO/2012/AndreMolina/AndreMolina]

3. Doufekas K, Duncan TJ, Williamson KM, Varma S, Nunns D: Mohs micrographic surgery for dermatofibrosarcoma protuberans of the vulva. Obstet Gynecol Int 2009, 2009:1-2.

4. Farma JM, Ammori JB, Zager JS, Marzban SS, Bui MM, Bichakjian CK, Johnson TM, Lowe L, Sabel MS, Wong SL, Douglas Letson G, Messina JL, Cimmino VM, Sondak VK: Dermatofibrosarcoma protuberans: how wide should we resect? Ann Surg Oncol 2010, 17:2112-2118.

5. Häfner HM, Moehrle M, Eder S, Trilling B, Röcken M, Breuninger H: 3D Histological evaluation of surgery in dermatofibrosarcoma protuberans and malignant fibrous histiocytoma: Differences in growth patterns and outcome. Eur J Surg Oncol 2008, 34:680-686.

6. Hammonds LM, Hendi A: Dermatofibrosarcoma protuberans of the vulva treated using mohs micrographic surgery. Dermato/ Surg 2010, 36:558-563.

7. Bertolli E, Campagnari M, Molina AS, Macedo MP, Pinto CA, Cunha IW, Duprat Neto JP: Artificial dermis (Matriderm ${ }^{\circledast}$ ) followed by skin graft as an option in dermatofibrosarcoma protuberans with complete circumferential and peripheral deep margin assessment. Int Wound J 2013, 19.

8. Chan JK, Sugiyama V, Tajalli TR, Pham H, Gu M, Rutgers J, Monk BJ: Conservative clitoral preservation surgery in the treatment of vulvar squamous cell carcinoma. Gynecol Oncol 2004, 95:152-156.

9. Forner DM, Dakhil R, Lampe B: Can clitoris-conserving surgery for early vulvar cancer improve the outcome in terms of quality of life and sexual sensation? Eur J Obstet Gynecol Reprod Biol 2013, 171:150-153.

10. Soltan $\mathrm{MH}$ : Dermatofibrosarcoma protuberans of the vulva. $\mathrm{Br} J$ Obstet Gynaecol 1981, 88:203-205.

11. Agress R, Figge DC, Tamimi H, Greer B: Dermatofibrosarcoma protuberans of the vulva. Gynecol Oncol 1983, 16:288-291.

12. Bock JE, Andreasson B, Thorn A, Holck S: Dermatofibrosarcoma protuberans of the vulva. Gynecol Oncol 1985, 20:129-135.

13. Barnhill DR, Boling R, Nobles W, Crooks L, Burke T: Vulvar dermatofibrosarcoma protuberans. Gynecol Oncol 1988, 30:149-152.

14. Leake JF, Buscema J, Cho KR, Currie JL: Dermatofibrosarcoma protuberans of the vulva. Gynecol Oncol 1991, 41:245-249.

15. Panidis D, Rousso D, Achparaki A, Georgiadis H, Vlassis G: Recurrence of dermatofibrosarcoma protuberans of the vulva. A clinical, histological, and ultrastructural study. Eur J Gynaecol Oncol 1993, 14:182-186.

16. Aartsen EJ, Albus-Lutter CE: Vulvar sarcoma: clinical implications. Eur J Obstet Gynecol Reprod Biol 1994, 56:181-189.

17. Karlen JR, Johnson K, Kashkari S: Dermatofibrosarcoma protuberans of the vulva. A case report. J Reprod Med 1996, 41:267-269.

18. Nirenberg A, Ostör AG, Slavin J, Riley CB, Rome RM: Primary vulvar sarcomas. Int J Gynecol Pathol 1995, 14:55-62.

19. Alverez-Cañas MC, Mayorga M, Fernandez F, Val-Bernal JF, Moral E, Leon C, Erasun F, Lerma D: Dermatofibrosarcoma protuberans of the vulva: clinico-pathological, immunohistochemical and flow cytometric study of a case. Acta Obstet Gynecol Scand 1996, 75:82-85.

20. Soergel TM, Doering DL, O'connor D: Metastatic dermatofibrosarcoma protuberans of the vulva. Gynecol Oncol 1998, 71:320-324.

21. Ghorbani RP, Malpica A, Ayala AG: Dermatofibrosarcoma protuberans of the vulva: clinicopathologic and immunohistochemical analysis of four cases, one with fibrosarcomatous change, and review of the literature. Int J Gynecol Pathol 1999, 18:366-373.

22. Moodley M, Moodley J: Dermatofibrosarcoma protuberans of the vulva: a case report and review of the literature. Gynecol Oncol 2000, 78:74-75.

23. Vanni R, Faa G, Dettori T, Melis GB, Dumanski JP, O'Brien KP: A case of dermatofibrosarcoma protuberans of the vulva with a COL1A1/PDGFB fusion identical to a case of giant cell fibroblastoma. Virchows Arch 2000, 437:95-100

24. Kholová I, Ryska A, Dedic K: Composite tumor consisting of dermatofibrosarcoma protuberans and giant cell fibroblastoma associated with intratumoral endometriosis. Report of a case. Pathol Res Pract 2001, 197:263-267.

25. Ohlinger R, Kühl A, Schwesinger G, Bock P, Lorenz G, Köhler G: Dermatofibrosarcoma protuberans of the vulva. Acta Obstet Gynecol Scand 2004, 83:685-686.

26. Hancox JG, Kelley B, Greenway HT Jr: Treatment of dermatofibroma sarcoma protuberans using modified Mohs micrographic surgery: no recurrences and smaller defects. Dermatol Surg 2008, 34:780-784. 
27. Zizi-Sermpetzoglou A, Savvaidou V, Fournogerakis S, Moustou E, Konstantidelli M, Vlachakos N: Dermatofibrosarcoma protuberans of the mons pubis. Eur J Gynaecol Oncol 2012, 33:537-539.

28. Gökden N, Dehner LP, Zhu X, Pfeifer JD: Dermatofibrosarcoma protuberans of the vulva and groin: detection of COL1A1-PDGFB fusion transcripts by RT-PCR. J Cutan Pathol 2003, 30:190-195.

29. Pamplona DC, Weber HI, Leta FR: Optimization of the use of skin expanders. Skin Res Technol 2014, 20:463-472.

doi:10.1186/1477-7819-12-399

Cite this article as: Bertolli et al:: Dermatofibrosarcoma protuberans of the vulva: margins assessment and reconstructive options - a report of two cases. World Journal of Surgical Oncology 2015 12:399.

\section{Submit your next manuscript to BioMed Central and take full advantage of:}

- Convenient online submission

- Thorough peer review

- No space constraints or color figure charges

- Immediate publication on acceptance

- Inclusion in PubMed, CAS, Scopus and Google Scholar

- Research which is freely available for redistribution 